\section{Kuram ve Uygulamada SOSYAL BİLİMLER DERGİSİ}

Aralik 2021

Yil: 5 Sayı: 2 ss. 231-247

Makale Türü: Araştırma Makalesi

Geliş Tarihi: 03.12.2021

Kabul Tarihi: 27.12.2021

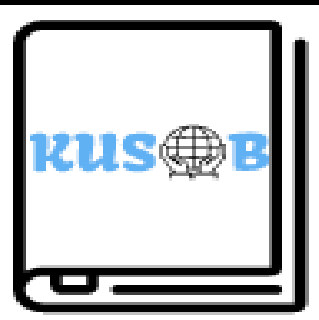

ISSN: 2619-9408
SOCIAL SCIENCES:

Theory \& Practice

December 2021

Volume: 5 Issue: 2 pp. 231-247

Article Type: Research Article

Submitted: 03.12.2021

Accepted: 27.12.2021

\title{
CUMHURIYYTIN İLK YILLARINDA HALKI YOKSULLAŞTIRAN SALGIN: VEBA-İ BAKARÎ
}

\begin{abstract}
Abdulaziz KARDAŞ*
ÖZ

Salgın hastalıklar, tarih boyunca insan varlığını ve toplumları tehdit eden önemli bir unsur olmuştur. İnsanları etkileyen salgın hastalıkların yanında geçim kaynağı olan hayvanları yok eden salgınlar da bulunmaktadır. Veba-i bakarî, tarih boyunca hayvan hastalıkları arasında büyük kayıplara sebep olmuş salgınların başında gelmiş ve bütün dünyada özellikle doğu ülkelerinde büyük iktisadî zararlara yol açmıştır. Salgın, bütün dünyada olduğu gibi Osmanlı Devletini de etkilemiş ve ülke hayvancılığına kayıplar verdirmiştir. Birinci Dünya Savaşı ve Millî Mücadele dönemlerinde veba-i bakarî cephelerde savaşan ordunun nakliye ve beslenmesinde kullanılan sığırları yok etmiştir. Cumhuriyet Döneminde veba-i bakarî, nüfusunun büyük bir bölümünün hayvancılıkla geçinen Türkiye'nin ekonomik hayatına oldukça olumsuz etkiler yapmıştır. Bu nedenle Cumhuriyetin ilanından sonra da hastalığa karşı mücadeleler verilmiştir. Cumhuriyetin ilk yıllarında veba-i bakarî, mücadelede kullanılan serumun ve yeterli sayıda baytar teşkilâtının bulunmaması nedeniyle kısa süreler içinde geniş alanlara yayılma imkânı bularak büyük ölçüde hayvan ölümlerine yol açmıştı. Bu dönemde hayvanların veba-i bakarîden korunması için idari, sıhhi ve inzibati tedbirler alınmış, sınırların muhafazası ve gümrük teşkilâtlarının sıkı bir iş birliğiyle hastalık yok edilmiştir.
\end{abstract}

Anahtar Kelimeler: Türkiye, Salgın Hastalıklar, Veba-i Bakarî.

\section{The Epidemic That Impoverished the People in the First Years of the Republic: Rinderpest}

\begin{abstract}
Epidemics have been an important factor threatening human existence and societies throughout history. In addition to epidemics that affect humans, there are also epidemics that destroy livelihood animals. Rinderpest has been one of the leading epidemics that have caused great losses among animal diseases throughout history and has caused great economic losses all over the world, especially in eastern countries. The epidemic affected the Ottoman Empire as well as the whole world and caused losses to the country's livestock. During the First World War and the National Struggle, the rinderpest destroyed the cattle used in the transportation and feeding of the army fighting on the fronts. In the Republican Era, the rinderpest had a very negative impact on the economic life of Turkey, where a large part of the population lived on animal husbandry. For this reason, after the proclamation of the Republic, struggles were made against the disease. In the first years of the Republic, rinderpest had the opportunity to spread to large areas in a short time due to the lack of serum used in the fight and the lack of sufficient number of veterinary organizations, leading to animal deaths to a large extent. In this period, administrative, sanitary and disciplinary measures were taken to protect animals from rinderpest, and the disease was eradicated with the close cooperation of the borders and customs organizations.
\end{abstract}

Keywords: Turkey, Epidemics, Rinderpest.

\footnotetext{
* Doç. Dr., Van Yüzüncü Y1l Üniversitesi, Edebiyat Fakültesi, Tarih Bölümü, e-Posta: a.kardas@yyu.edu.tr ORCID: 00000002-3343-2745
} 


\section{Giriş}

Salgın hastalıklar, tarih boyunca insan varlığını ve toplumları tehdit eden önemli bir unsur olmuştur. İnsanları etkileyen salgın hastalıkların yanında halkın temel geçim kaynağı olan hayvanları yok eden salgınlar da bulunmaktadır. Bu bağlamda veba-i bakarî, tarih boyunca hayvan hastalıkları arasında büyük kayıplara sebep olmuş salgınların başında gelmiştir. Veba-i bakarî, bütün dünyada özellikle doğu ülkelerinde zaman zaman afet halini almıştı. Hastalığın girdiği kıtalarda yüzbinlerce hayvanın yok olmasına ve devletlerin büyük iktisadî zararlara uğramasına yol açmıştı (Vakit, 11 Mart 1930). Bu yönüyle veba-i bakarî önemli bir afet olarak insanlık tarihindeki yerini almıştır. Türkiye, bulunduğu coğrafi konumunun da etkisiyle veba-i bakarînin neden olduğu yıkımlara maruz kalmıştır.

Veba-i bakarî virüsü hasta hayvanların ağız, mide, bağırsak, kan, gözyaşı, burun akıntısı, salya, idrar, et ve derisine temas eden her türlü araç ile ot, saman, gübre ve su vasitasıyla bulaşır. Veba-i bakarî virüsü hayvanın vücuduna girdikten sonra belirtilerini üç ile dokuz gün arasında gösterir (Ak, 2016, 216-217).

Veba-i bakarî, halk arasında sığır vebası, malkıran ve çor adlarıyla anılmaktadır (A.Ş. Akşam, 25 Teşrinievvel 1938.). Anadolu'da veba-i bakarî salgınları çok eski tarihlerden beri etkili olmaktaydı. Kökünü Asya'dan alan hastalık çoğu zaman Karadeniz'in kuzey sahilleri ve bazen de Anadolu yarım adası üzerinden Balkanları aşarak Avrupa'ya bulaşmıştır. Osmanlı Devleti'nde sıklıkla ortaya çıkan hastalık büyük telefata yol açmaktaydı. 1877-1878 Osmanlı-Rus Savaşı'nda İstanbul üzerinden Balkanlara sıçrayan hastalık, buralarda sefalete sebep olacak derecede zayiat verdirmişti. Savaştan sonra Doğu vilâyetlerinde büyük kayıplara sebep olan hastalık daha sonra yurdun her tarafına yayılmıştı. Osmanlı Devleti'nin son döneminde veba-i bakarî gibi salgı̀n hayvan hastalıklarıyla mücadele etmek amacıyla harekete geçilmiş, 1893'te Zabıta-i Sihhiye-i Hayvaniye Talimatnamesi kabul edilmiş ve ilk önce Bursa'da uygulanmasına karar verilmişti (Erk ve Akkerman, 1969, 10-12).

Aralık 1897'de Çatalca ve Küçükçekmece'de etkili olan veba-i bakarîye karşı zabıta kuvveti artırılmış, kasaplık hayvanlarla ilgili kısıtlamalar getirilmiş ve öküz ile manda arabalarının İstanbul'a girişleri yasaklanmıştı (BOA, BEO. 1061.79522). 12 Ekim 1898'de Aydın Vilâyeti ve Yozgat Sancağı'nda etkisini gösteren hastalığa, yakalanan hayvanlara serum vermek üzere bakteriyolog ve baytar memurlarının yeterli miktarlarda serumla bölgeye gönderilmeleri istenmişti (BOA, BEO, 1209. 90669). 5 Aralık 1906'da Aydın Vilâyeti'nde yeniden çıan ve günden güne yayılmaya başlayan vebai bakarî ile mücadele için gerekli miktarda baytar, serum ve gardiyanların gönderilmesi kararlaştırılmıştı (BOA, BEO, 2957. 221720.). 22 Aralık 1906'da Kastamonu Vilâyeti'nde etkili olan hastalığın yayılmasını önlemek amacıyla gerekli önlemler alınmıştı (BOA, BEO, 2967. 222490.).

1893'te çıarılan "Zabıta-i Sihhiye-i Hayvaniye Talimatnamesi" 1913 yılına kadar uygulanmıştı. 1913'te 45 maddelik "Zabıta-i Sihhiye-i Hayvaniye Kânunu Muvakkatı" çıkarılmıştı. $\mathrm{Bu}$ kanunun 4. maddesi; "hasta ve hastalarla temas eden hayvanlar itlaf edilir." şeklindeydi. Kânunun 17. maddesinde itlaf ve tazminata yer verilmişti. Bir yıl sonra bu kânuna ilave olarak 92 maddelik "Zabıta-i Sihhiye-i Hayvaniye Talimatnâmesi" çıkarılmıştır (Erk ve Akkerman, 1969, 1112). Çıkarılan kânun ve talimatnâmelere rağmen yeterli baytar ve veba-i bakarî serumunun bulunmaması nedeniyle salgınla gerektiği şekilde mücadele edilememişti.

\section{1) Birinci Dünya Savaşı ve Millî Mücadele Dönemlerinde Veba-i Bakarî ile Mücadele}

Veba-i bakarî, Birinci Dünya Savaşı sırasında zaman zaman orduların hareket kabiliyetini sarsacak derecede büyük kayıplar verdirmişti. Çanakkale Savaşı'nda taşımacılıkta kullanılan gemilerin önemli bir kısmının düşman deniz altıları tarafından Marmara'da torpillenerek batırılması ve deniz 
yolunun tehdit altında bulunması nedeniyle savaşa katılan birliklerin cephane ve yiyecekleri ile diğer savaş araçlarının taşınma işi Uzunköprü-Keşan-Aksamil-Gelibolu istikametinde faaliyette bulunan sığır arabalarıyla yapılmıştı. Ancak bu nakliye kollarına gerilerden bulaşan ve iaşe sığırlarıyla da cepheye kadar yayılan hastalığın yaptığı tahribat, birliklerin savaş gücünü tehdit edecek duruma getirmişti. Hastalıkla mücadele etmek için en önemli vasıta olan serumun zamanında ve yeteri miktarda yetiştirilememesi mücadele işlerini aksatmış, karantina altına alınan nakliye kollarının uzun zaman hareketsiz kalmalarına sebep olmuştur (Erk ve Akkerman, 1969, 14-15).

Birinci Dünya Savaşı koşulları ve yetişmiş insan gücünün yetersizliği salgın hayvan hastalıkları ile mücadelede güçlüklerin yaşanmasına sebep olmuştu. 8 Ağustos 1915'te Sivas Valiliği'nden Dâhiliye Nezareti'ne çekilen telgrafta; halkın nakliye aracı olan hayvanlarda veba-i bakarînin zuhur ettiği ve yayılmaya başladığı, vilâyette baytar mıntıkasından başka fen memuru bulunmadığından iki-üç askerî baytarın süratle gönderilmesinin sağlanması istenmişti (BOA, DHŞFR, 483. 19.).

Mondros Ateşkes Antlaşması'ndan sonra halkın hayvanlarında veba-i bakarînin bulunduğu mahaller, Antep, Bilecik, Adana, Ardahan, Batum ve sair bir takım köylerde ve Ekim 1919'da Edirne, İzmir, Ankara, Erzurum, Afyon ve Eskişehir'in bazı köylerinden ibaretti. Bu dönemde Batum ve Ardahan'da halkın ve Samsun'da da askerin iaşe hayvanlarında veba-i bakarî tespit edilmişti (Baytarî Harp Tarihi, 1933, 5).

Millî Mücadele başladığı zaman görevde bulunan sınırlı sayıdaki asker ve sivil baytarların çabalarına rağmen veba-i bakarî yurdun her tarafını sarmıştı. Salgın, doğudan batıya doğru yayılmadan önce 1919 yılında Ankara civarında, 57. Fırka'nın bulunduğu Köşk ve Nazilli'de ve 1920 yılında da Geyve'nin birkaç köyünde ortaya çıkmıştı. Bütün uyarılara rağmen 12. Fırka; iaşe, nakliye ve subaylarına ait öküz ve inekleriyle hastalığı doğudan batıya doğru taşıyarak Sivas'a bulaştırmıştı. Sivas'ta veba-i bakarînin ortaya çıkması, orduyu ve halkı telaşlandırmış, karantinalar uygulanmış ve çekilen telgraflarla hastalığın daha ileri geçmesine engel olacak tedbirler alınmak istenilmişse de başarılı olunamamıştı. Hastalık bulaştıktan sonra da Tekâlif-i Milliye Emirleri doğrultusunda ülkenin birçok farklı yerinden toplanan sığırlar batıya doğru sevk edilmeye devam edilmişti. Böylece veba-i bakarî hemen hemen her yere bulaşmış olduğundan artık bunun önüne geçmek mümkün olmamıştı (Baytarî Harp Tarihi, 1933:112-113). Hastalık, Orta Anadolu'yu aştıktan sonra Batı Cephesine kadar yayılmıştı. Batı Cephesi Kumandanlığı'ndan 17 Aralık 1921'de İcra Vekilleri Heyeti Riyaseti'ne çekilen şifreli tel yazısı, hastalığın neden olduğu korkuyu göstermekteydi. ${ }^{1}$

Millî Mücadele sırasında orduyu saran veba-i bakarîye karşı serum hazırlamak üzere Millî Müdafaa Vekâleti'nin verdiği yetki ile Ankara Etlik'te Baytarlık İşleri Dairesi'ne bağlı bir bakteriyolojihane kurulmuştu. Burada bir serum şubesi açılmış ve 20 Nisan 1922'den itibaren her türlü tahlillere başlamıştı (Baytarî Harp Tarihi, 1933, 6). Etlik’te Emval-i Metruke binalarında kurulan serum laboratuvarının malzemesinin önemli bir kısmı Ulus Meydanı'ndaki Koç Hanı'nda bulunan bakteriyoloji laboratuvarından sağlanmıştı. Çok zor şartlar altında çalışan bu askerî serum laboratuvarında üretilen serumlar ordunun ihtiyacını karşılamış ve bilhassa Büyük Taarruz sırasında iyi hizmetler görmüştü. Bu kurum savaştan sonra yine Etlik'te kurulan Askerî Bakteriyoloji Enstitüsü'nün çekirdeğini oluşturmuştu (Erk ve Akkerman, 1969, 74-75).

\footnotetext{
${ }^{1}$ Batı Cephesi Kumandanı İsmet Bey'in yazısı şu şekildeydi: “İcra ettiğim tetkikata nazaran vebayı bakarî salgını Sivas'tan gelmiş ve orduyu tehlikeli bir surette istila eylemiştir. Mudafaa-i Milliyece köylerde ne gibi tedbir ittihaz edildiğini bilemiyorum. Ancak Sivas 'tan itibaren bu salgının getirilip orduya bulaşmasına mani olmak Garp cephesinin değil, Iktisat Vekâleti'ne mütealliktir. Alâkadarların vazifesini ifa etmediğinden müştekiyim. Şikâyetimi ve ittihazı muktezi tedbiri Heyet-i Vekile'de mevzuu bahsetmenizi istirham ederim. Orduyu sarmış afetin ne avakıp vereceğini tayin etmek kudreti beşer dâhilinde değildir." Nihal Erk, Naki Cevat Akkerman, Türkiye'de Sı̆̆ır Vebası Salgınları ve Eradikasyonu Tarihi, Ankara Üniversitesi Veteriner Fakültesi Yayını, Ankara 1969, s.15.
} 
Suriye'de askerî harekâtta bulunan Fransızlardan kaçan köylülerin yanlarında getirdikleri vebalı sı̆̆ırlarla hastalık, 1921'de Türkiye'nin güneyindeki vilâyetlere bulaşmıştı. Kısa bir zaman zarfında bütün Anadolu'yu istila eden hastalığa karşı, orduya mensup baytar teşkilâtı ve İktisat Vekâleti'nin bütün kuvvetleri seferber edilmişti. Ayrıca, Eskişehir'in Yunanlılar tarafından işgali üzerine Ankara'ya nakledilen ve Erzincan'da bulunan serum kurumları faaliyete geçirilmişti. Sonraki aylarda genişleyen veba-i bakarî ile mücadele için bazı vilâyetlerde baytar bulunmaması nedeniyle hastalık önemli zararlara yol açmıştı (Erk ve Akkerman, 1969, 85-86).

Erzurum, Kars, Sarıkamış ve Oltu civarında da etkisini sürdüren veba-i bakarî ile mücadelede sivil baytarların yetersiz kalmaları üzerine 24 Aralık 1921'te Erzurum Mebusu Nusret ve arkadaşları TBMM'ye bir yazı göndererek askerî baytarların da bu mücadelede görevlendirilmeleri hususunda Müdafaa-i Millîye Vekâleti'ne gerekli talimatın verilmesini teklif etmişlerdi. Yapılan yazışmalar sonunda Müdafaa-i Millîye Vekâleti, Erzurum havalisindeki veba-i bakarî için cepheden iki askerî baytarı Erzurum Baytar Müfettişliği emrine vermişti (BCA, 030.10.186.282.2.). Türkiye'nin doğusundan ve güneyinden yayılan salgına karşı harekete geçirilen serum kurumları ve baytarların çalışmaları kısa sürede olumlu sonuçlar vermişti.

Ancak 1922 yılında veba-i bakarî yeniden halkın ve askerin sığırlarına kayıplar verdirmeye başlamıştı. Hastalık, Amasya, Samsun, Havza, Merzifon, Köprü, Osmancık, Sungurlu gibi birçok bölgede devam ettiğinden İktisat Vekâleti'nin nezareti altında ve Hayvan Sağlı Zabıtası Komisyonu'nun kararıla baytar ve stajyer baytarlardan oluşan daimî mücadele heyetleri oluşturulmuştu. $\mathrm{Bu}$ dönemde askeri anlamda Yunanlılara karşı mücadele hazırlıklarına başlanmış ve serum üreten kurumlarda da yoğun çalışmalar başlatılmıştı. Baytarlık İşleri Dairesi'nden Millî Müdafaa Serum Müessesesi Müdiriyeti'ne 17 Temmuz 1922'de yazılan tezkerede; “ordunun muhtemel bir hareket için fazla miktarda serum üretimine mecburiyet hâsll olduğundan ayda 300 litre olan üretimin 450 litreye çıkarllması için eksikliklerin süratle tamamlanması" istenmişti (Baytarî Harp Tarihi, 1933, 23-24).

Veba-i bakarînin Millî Mücadele yıllarında yaptı̆̆ı tahribatı değerlendiren İktisat Vekili Mahmud Esad Bey; Orta Anadolu'da veba-i bakarînin yok denebilecek bir hale geldiğini, bazı köylerde tek tük vakalar görüldüğünü, Rusya'dan kurtarılan vilâyetlerde hastalığın yeniden başladığını açıklamıştı. Mahmud Esat Bey, Çanakkale'de veba-i bakarînin şiddetle hüküm sürdügünü, bunun askerî harekâttan kaynaklandığını ve gereken tedbirlerin alınarak askeriyeden 30 baytarın bölgeye gönderildiğini ifade etmişti. Mahmud Esat Bey, veba-i bakarînin yaptığı tahribat hakkında; "Veba-i bakarî maatteessüf memleketimizde çok büyük tahribat yapmıştır ve bu tahribat tahmin edemeyeceğimiz kadar fazladır. Elimizdeki istatistiklere nazaran resmî olarak 50-60 bin siğır telef olmuştur. İhtimal ki haber alamadığımız daha birçok hayvanat vardır. Miktarını şu suretle 100 bine çıkarabiliriz. Bunlar 30'ar liradan 3 milyon lira eder ve bu serveti millîyemizdendir ve bilhassa en fakir halkımı tarafindan kaybedilmiştir... Efendiler; elimizde baytar yoktur ve hepsi vazife-i askeriyesini ifa ile mükelleftir. Birçok defa Müdafaa-i Millîye'den istedik. Fakat ordu lüzumuna binaen bunlart terhis edemedi. Bütün Anadolu'daki veba-i bakarîyi yalnı 120 baytar ile tedaviye çalıştık... Fakat maalesef vesaiti nakliyenin fikdanı ve Çanakkale'nin malûm olan vaziyeti bunların vakit ve zamaniyle tedavi mahalline girmesine mâni oluyordu. Elimizden ne geldiyse hepsini yaptık," (TBMM ZC, D:1, C:26, İ:165, (30.12.1922):111, 119) açıklamasını yaptı.

\section{2) Cumhuriyet Dönemi'nde Veba-i Bakarî İle Mücadele}

Veba-i bakarî, Millî Mücadele'den sonra da nüfusunun yüzde 75 'inden fazlası tarım ve hayvancılıkla geçinen Türkiye'nin ekonomik hayatına oldukça olumsuz etkiler yapmaktaydı. Bu nedenle Cumhuriyetin ilanından sonra da veba-i bakarîye karşı mücadeleler verilmişti. Veba-i bakarî, bu dönemde de ağırlıklı olarak doğu ve güney sınır bölgelerinden kaçak olarak yurda sokulan aşiret ve 
göçebe hayvanlarından bulaşmıştı. Ülkenin temel ekonomi kaynağı, halkın geçim vasıtası olan hayvanların her türlü salgından ve özellikle veba-i bakarîden korunmasına yönelik amaçların her bakımdan gerçekleşmesi için korunma tedbirlerini idare, inzibat ve teknik makamlarla sınır muhafazası ve gümrük teşkilâtları tarafından sıkı bir iş birliğiyle uygulanması zorunlu hale gelmişti (İdare Dergisi, 1942 :39-40). Tarihin eski zamanlarından beri Türkiye'de yerleşmiş bulunan veba-i bakarînin kökünden kaldırılması ile yılda binlerce hayvanın telef olmasından doğan büyük zararların önüne geçilmiş olacaktı (Birinci Köy, 1939:220). Bu mücadele ve imha köylünün tarım ve hayvancılık yönünden kalkınmasının başlıca etkenlerinden biri olacaktı (BCA, 030.10.13.77.25.).

Zirâ Cumhuriyet döneminde hayvancılığı oldukça olumsuz bir şekilde etkileyen veba-i bakarî her yıl 20.000'den fazla sığırın telef olmasına neden olmaktaydı. (1940-1941 Ders Y1lı, 1940:6). Veba-i bakarî, Cumhuriyetin ilk yıllarında hayvancıllı̆ın gelişmesinin önündeki en önemli engel olarak görülmüştü. Mücadelede kullanılan serumun ve yeterli sayıda baytar teşkilâtının bulunmaması nedeniyle hastalık, kısa süreler içinde geniş alanlara kadar yayılma imkânı bularak büyük ölçüde hayvan ölümlerine yol açmıştı. (TBMM ZC, D:I, C:23, İ: 118:367). Cumhuriyet öncesinde, hayvan hastalıkları ile mücadele konusunda, veba-i bakarî serumu yanında, koyun çiçeği, mallein, tüberkülin ve barbon aşılarının üretildiği Erzincan Serum Laboratuvarı ve Pendik Bakteriyoloji Enstitüsü isminde iki kurum bulunmaktayd. Cumhuriyetin ilanından hemen sonra, Etlik'te bir kurum daha açılarak burada da üretim faaliyetleri başlatılmıştı (Gül, 2004:238-239). Bu kurumlarda üretilen serumların kullanılması ve hastalığın yayılmasının önlenmesi amaciyla 1923'te kordon (karantina) sisteminin getirilmesi, Anadolu'daki hayvan ölümlerini azaltmıştı. Anadolu'da her yıl binlerce hayvanın yok olmasına sebep olan, köylüyü çiftinden mahrum ederek sefalete sürükleyen veba-i bakarînin ortadan kaldırılması Cumhuriyet hükümetlerine nasip olmuştur (Doğu, 1938,41).

İktisat Vekâleti, 1923 yılının başında Tokat ve köylerinde etkisini sürdüren ve bu bölgedeki hayvanları yok eden veba-i bakarîye karşı harekete geçmişti. İlk etapta bölgeye 186 litre 935 gram serum ve 51.740 lira gönderilmiş ve alınan sıkı önlemlerle hastalık söndürülmüştü (TBMM ZC, D:1, C:28, İ:8 (21.3.1339):111-112.). İcra Vekilleri Heyeti, 22 Temmuz 1923’te İzmir çevresi ile İzmit ve Çanakkale vilâyetlerinde ortaya çıarak yayılmaya başlayan veba-i bakarînin önlenmesi amacıyla çalıştırılacak 3 memura ait ücretin Emraz-1 Sâriye-i Hayvaniyye Tertibi'nden ödenmesini kararlaştırmıştı (BCA, 030.18.01.01.7.25.9.).

Veba-i bakarî, 1924 yılında Rusya'nın Tahçıran ve Kız bölgelerinden kaçak olarak geçen göçmen kafilesiyle sınır üzerinde bulunan Kızılçakçak'ın Uzun Kilise Köyü’ne bulaşmış ve civarda bulunan beş köye yayılmıştı. (Erk ve Akkerman, 1969: 21). Veba-i bakarînin memleketten tamamıyla yok edilmesini sağlamak amacıyla Baytar Mektebi tarafından düzenlenerek 20 Mart 1924'te Ziraat Vekâleti'ne gönderilen talimatnâme İcra Vekilleri Heyeti'nce 3 Nisan1924'te kabul edilmişti (BCA; 030.18.01.01.9.20.2.). Talimatnâme, veba-i bakarînin ülkeden tamamen yok edilmesini sağlamay1 amaçlamıştı. 20 maddeden oluşan talimatnâmede genel olarak vali, kaymakam ve jandarma kumandanlarının işbirliği ile alınabilecek önlemler, herhangi bir bölgeden veba-i bakarî ihbarı yapıldığı halde gerekli önlemleri zamanında almayarak hastalığın yayılmasına neden olan idarecilerle, hastalığı civar kaza ve vilâyetlere zamanında ihbar etmeyen baytar ve yerel yöneticilerin cezalandırılması, seyyar mücadele heyetleri ve bunlara ödenecek ücretler, hastalıklı bölgelerde itlaf edilen hayvanların gömülmesi, sahiplerine tazminat ödenmesi, temizlik önlemleri, hastalıklı bölgelerden hayvan ve hayvan maddeleri nakliyatının yasaklanması gibi başlıca hükümler yer almıştı (Temel, 2010, 13).

Ziraat Vekâleti'nden 5 Haziran 1924'te Başvekâlet'e ve 7 Haziran 1924'te Başvekâlet'ten Müdafaa-i Millîye Vekâleti'ne gönderilen yazıda; veba-i bakarî ile mücadele etmekte olan baytarların silah altına alınması sebebiyle sayılarının azalarak salgının artmaması için askerliklerinin tecillerinin 
sağlanması gerektiği bildirildi (BCA, 030.10.186.282.9.). Buna 25 Haziran 1924'te cevap veren Müdafaa-i Millîye Vekâleti, gönderdiği yazıda; Ziraat Vekâleti'nden aynı doğrultuda gönderilen talep üzerine Mülkiye Baytar Mektebi mezunlarının eylül sonuna kadar sevklerinin ertelenmesi hususu asker alma dairelerine yazıldığı fakat bir müddetten fazla tehirleri uygun bulunmadığından dolayı belirtilen tarihe kadar "veba-i bakar̂̂" hastalığı söndürülmediği takdirde adı geçen memurların yerlerine başkaları tayin edilmek suretiyle askere alınacaklarını bildirdi (BCA, 030.10.57.381.13.).

Türkiye'nin iktisadî hayatında en mühim etken olan hayvanların sağliklarını korumak ve özellikle veba-i bakarînin tahripkâr salgınlarına karşı uygulanmakta olan serumun daha emin ve esaslı bir surette üretimini sağlamak için bir laboratuvarın kurulması çok gerekliydi. Pendik Bakteriyolojihanesi'nde veba-i bakarîye karşı ihtiyaç oranında serum üretimine imkân bulunmamaktaydı. Bu etkenler de dikkate alınarak Anadolu'nun uygun bir yerinde kurumun yeniden açılması kararlaştırılmıştı. Bu amaçla 1924 bütçesine 30 bin lira tahsisat konulmuştu. Yapılan araştırmalardan sonra uygun şartlara sahip görülen Eskişehir'deki Hasırcı Çiftliği, serum kurumu yapılmak üzere 25 Aralı 1924'te çıkarılan kararnâme ile istimlâk edilmişti (BCA, 030.18.01.01.12.64.16.).

Irak ve Suriye'den 1924'te Türkiye sınırını geçen aşiretler ve hayvan tacirleri bu ülkelerden getirdikleri vebalı hayvanlarla Siirt, Mardin, Ceyhan bölgelerine; doğudan Kars, Erzurum ve Ardahan'ın hasta hayvanları da Gümüşhane istikâmetinde Of, Sürmene ve Trabzon da bulaşma alanına girmişti. Hastalık Samsun, daha sonra tüccar ve hayvan sürekleri ile Çankırı, Kastamonu bölgelerine yayılmıştı. Bir taraftan sivil baytarların ordudan tamamen terhis edilmiş olmaları ve diğer taraftan kadro ve teşkilâtın daha müsait duruma getirilmiş olması hastalıkla mücadele işlerini daha sağlam bir şekle sokulmasına imkân sağlamıştı. (Erk ve Akkerman,1969, 89-90).

$\mathrm{Bu}$ dönemde kurulan Mücadele Heyetleri'nin çalışmalarıyla 1925'te bilhassa Giresun'dan Adana'ya çekilen bir hattın batısındaki saha hastalıktan tamamen temizlenmişti. Kars, Ardahan istikametinden Yozgat'ın Akdağmadeni'ne ve güneyde Irak sınırından Mardin ve Diyarbakır istikametine ve bu vilâyetlerin batı sınırlarından bir taraftan Malatya'nın Kahta, Adıyaman, diğer taraftan Urfa-Suruç-Birecik-Gaziantep istikametinden İslâhiye'ye kadar olan bölge yeni bir bulaşmaya maruz kalmıştı. Hastalık Haziran 1925'te Kars'a Ermenistan'dan getirilen hayvanlarla, Kağızman ve Çıldır bölgelerinde ise Rusya'dan getirilen hayvanlarla bulaşmıştı (Erk ve Akkerman, 1969, 89-93). Kars, Erzurum ve civardaki bölgelerde tüccar ve hayvan sahiplerinin hayvanlarını başka bölgelere nakletmesiyle hastalık iç bölgelere kadar yayılma imkânı bulmuştu. Güney vilâyetlerinde veba-i bakarî, Irak Musul bölgesinden getirilen hayvanlar ve bölgede hayvan tacirlerinin hayvanları ile Urfa, Mardin, Siirt ve Diyarbakır çevresine bulaşmıştı.

Türkiye'nin, değişik bölgelerinde 1925 yılında da etkili olan veba-i bakarî ile mücadele edilmiştir. Alınan tüm önlemlere rağmen Irak ve Suriye'den sınırı geçen aşiretler ve hayvan tacirleri bu ülkelerden getirdikleri hasta hayvanlarla hastalığ 1 güney ve güneydoğu Anadolu vilâyetlerine bulaştırmışlard. Ziraat Vekilliği'nden 26 Temmuz 1925'te Başvekâlete gönderilen tezkerede, Mardin ve Irak sınırları civarında çıkan veba-i bakarînin tamamen yok edilmesi için Türkiye ile Suriye ve Irak hükümetleri tarafindan ortak bir Hudut Sihhat Zabitası kurulmasına ihtiyaç bulunduğunu ve bu meselenin Şam'da toplanması kararlaştırılan Çekirge Konferansı'nda ele alınmasının gerekliliği bildirilmişti. Bu maksatla Bakteriyolojihane-i Baytarî Müdürü ve Baytar Mekteb-i Âlı̂’si Zabıta-i Hayvaniyye Muallimi Şefik Bey'in delege ve Umur-u Baytarî Müdürü Rasim Bey'in de müşavir sıfatıyla söz konusu konferansa katılmaları ve adı geçen meselenin ele alınması amacıyla Suriye ve Irak hükümetleri tarafinda delegelerinin gönderilmesi için Hariciye Vekâleti'nce Irak ve Suriye nezdinde gerekli girişimlerde bulunulması istenmişti. 26 Temmuz 1925'te İcra Vekilleri Heyeti 
yapılan teklifi kabul etmiş ve adı geçen Şefik ve Rasim beylere siyasî pasaport ve yevmiye verilmesini kararlaştırmıştı (BCA, 030.18.01.02.14.46.14.).

Eylül 1925 'te Erzurum ve çevresinde etkisini artıran veba-i bakarî bütün tedbirlere rağmen Yozgat'a kadar yayılmıştı. Bunun üzerine Ziraat Müsteşarı Süreyya Bey, Dâhiliye Vekili Cemil Bey’i ziyaret etmiş ve salgının durumu etraflıca ele alınmıştı. Süreyya Bey, jandarma ve Dâhiliye Vekâleti memurları yardımıyla kurulan kordonun daha güçlü bir şekilde takviyesi ile birlikte Yozgat ve özellikle Kızılırmak'ın batı kıyısında yeni bir kordonun kurulması gerektiğini ifade etmişti. Cemil Bey, bu konuda gerekli çalışmaları yapmış ve civar vilâyetlerin baytarlarını adı geçen bölgede toplayarak mücadeleyi başlatmıştı. (Cumhuriyet, 30 Eylül 1341.). Veba-i bakarînin yayılmasını önlemek için hastalığın bulunduğu bölgelere hayvanların sokulması yasaklanmıştı (BCA, 030.18.01.01.16.70.20.). Doğu Anadolu'dan Orta Anadolu'ya kadar yayılan, sivil ve askeri baytarlar ile veba-i bakarî mücadelesine hız verildiği bir sırada askeri tebligata rağmen vazifesine gitmeyerek görev mahallini terk eden Ankara baytarlarından Hüsnü Efendi'nin bu hareketi, hastalığın yayılmasına fırsat verdiğinden etkili bir ibret olması için Ankara İstiklâl Mahkemesi'ne verilmişti (BCA, 030.18.01.01.16.66.2.).

Ziraat Vekili Mehmet Sabri Bey, 31 Ekim 1925'te (Yücebaş, 2019, 108), Başvekâlete gönderdiği açıklamada; veba-i bakarînin memleketten tamamen kaldırılması için alınacak tedbir ve düzenlere dair olan ve 1924 y1lında uygulamaya konulan Mücadele Talimatnâmesinin uygulanmasından iyi neticeler alındığını fakat 1925 Muvazene-i Umumiye Kanunu'yla talimatnâmenin dokuzuncu maddesi hükümden kaldırıldığından, memuriyetlerinin bulunduğu asıl mahallerden geçici olarak veba-i bakarînin hüküm sürdüğü uzak bölgelere gönderilen, fen memurlarının mezkûr dokuzuncu madde ile almakta oldukları aylık 60 liranın Mücadele Talimatnâmesinde kendilerine tahsis olunan yevmiye mukabili aylık ücretlerinin eskisi gibi verilmesi için hazırlanan beş maddelik kanun layihasının onaylanmasını istedi (TBMM ZC, D:2, C:19, İ:12, (21.11.1925):174). Bunun üzerine 21 Kasım 1925'te 668 say1lı "Vazife-i Memureleri Haricinde Emraz-ı Sariye-i Hayvaniye Mücadelesine Memur Edilecek Memurin-i Fenniye ve Saireye Verilecek Yevmiyeler Hakkında Kanun" kabul edildi. Buna göre baytar, idari, askeri memurun ilgili bölgeye görevlendirilmesi esas alınmış ve kânun ile memurlara harcırah ve zorunlu ihtiyaçları haricinde 60 lira verilmişti (Resmî Ceride, 26 Teşrinisani 1341).

Ziraat Vekâleti Müsteşarı Süreyya Bey, TBMM'de yaptığı konuşmada; Veba-i bakarînin her yıl Türkiye'de önemli tahribat yaptığını Rumeli’ye kadar yayılmış olan hastalığın alınan tedbirlerle önüne geçildiğini söylemiştir. Fakat buna rağmen Irak, Suriye, İran ve Ermenistan'dan devamlı olarak yapılan hayvan nakliyatı dolayısıyla veba-i bakarînin tekrar ortaya çıktığını belirtmiştir. Süreyya Bey, Mardin, Diyarbakır ve Erzurum havalisinde Haziran 1925'te çıkan hastalığın gerekli tedbirlerin alınmasına rağmen Kars, Erzurum, Erzincan, Trabzon, Beyazit ve güneyde Mardin, Siverek, Diyarbakır, Urfa, Malatya ve Cebelibereket'e yayıldığını ifade etmiştir. Süreyya Bey, konuşmasının devamında; "bu hastalı̆̆ gelecek sene sıfira indirmek için birtakım tedabir ittihaz ettik. Meselâ Diyarbekir'de de serum darülistihzarl yapmaktayı, Pendik, Diyarbekir ve Erzincan'da olmak üzere üç serum fabrikası olacaktır. Bundan maada bu hastalık bizim memleketimize hariçten girdiği için Suriye hududunda, Iran hududunda ve Beyazıt civarında müteharrik üç heyeti baytariye dolaştıracağız. Bundan maada birtakım depolar tesis ediyoruz. Veba-i bâkarînin serumu bu memleketlerdeki depolarda daimi surette bulunacaktır. Binaenaleyh tertibatımı mükemmeldir, ”(TBMM ZC, D:2, C:19, İ:12, (21.11.1925):177) açıklamasını yapmıştır.

2 Aralık 1925'te Zabita-i Sihhiye-i Hayvaniye Kânunun 7, 17, 18, 19, 30 ve 39'uncu Maddelerinin Tadili Hakkında Kânun ile söz konusu maddelerinde yapılan değişikliklerle hastalık ihbarında bulunanlara verilecek ödül, tazminat kapsamına dâhil edilen hastalıklar ve tazminat 
miktarları belirlenerek güncellenmiştir (BCA, 030.10.186.282.14.). İcra Vekilleri Heyeti, 20 Aralık 1925 'te veba-i bakarîye karşı üretilmekte olan serum miktarının artırılması amacıyla serum ve serum laboratuvarları için gerekli maddelerin İstanbul'dan pazarlıkla satın alınmasını kararlaştırmıştı (BCA, 030.18.01.01.17.80.9.).

Doğu Anadolu'da veba-i bakarînin yaptığı tahribatı önlemek amaciyla Ziraat Vekâleti, bölgeye gezici mücadele heyetleri göndermişti. Heyetlerin başına Baytar Mekteb-i Âlî hocalarından Salgın Hastalıklar ve Bakteriyoloji Uzmanı Rıza İsmail Bey tayin edilmişti. Rıza İsmail Bey, burada yaptığı tetkiklerde halk arasında salgının İran'dan geldiği yönündeki kanaatin doğru olmadığını, salgının Pasinler Ovası'ndan yayıldığını tespit etmişti. Heyet, hastalığın yayılmasını önlemek amacıyla kordonların kurulması, hastalığa yakalanan hayvanların itlafı ve devletin çiftçilerin zararlarını telafi etmesi gerektiği yönünde bir rapor hazırlamıştı (Varlık, 31 Kânun-1 evvel 1341). Alınan önlemlerle salgının yayılması durdurulmuştu.

1926 y1lına gelindiğinde 1925 'te verilen çabalara rağmen Türkiye yeniden dört yönde veba-i bakarî salgınına uğramıştır. Bir taraftan 1925 istilasının acıklı tahribatının tamiri ile uğraşı1ırken diğer taraftan Kafkasya, İran, Irak ve Suriye sinırlarından yoğun salgın dalgaları bu sinırlar üzerindeki vilâyetleri aşmış kuzey ve güney bölgelerinde Samsun, Çorum, Yozgat ve diğer taraftan da Muş, Elazı̆̆g, Malatya, İslâhiye'ye kadar yayılmıştı. Irak ve Suriye'de hastalık tahribatına devam ederken Türkiye'ye gelen aşiretlere karşı konulamamıştı. Aşiretlerin dağınık bir halde veba-i bakarîye yakalanan sürüleriyle Türkiye'ye hareket etmeleri ve bunları mevcut kuvvetlerle durdurmaya imkân bulunmadığından, mücadele teşkilâtı emrine ek olarak 100 askerlik bir kuvvetin verilmesi kararlaştırılmıştı (Erk ve Akkerman, 1969, 98, 101).

Erzurum'da veba-i bakarînin yayılmış bulunmasından dolayı bu vilâyetten İstanbul'a nakledilmekte olan hayvanlar Zabıtayı Sihhiye-i Hayvaniye Kânunu'nu gereğince, 12 Temmuz 1925 'ten itibaren Erzurum'dan sığır ihracatı men edilmiş ve vilâyet kordon altına alınmıştı. Ocak 1926'da hastalık Erzurum'un 4 köyüne daha yayılmıştı. Gerekli önlemler alındıktan sonra 11 Ocak 1926'da Erzurum'dan İstanbul'a gönderilecek hayvanların Trabzon yoluyla nakledilmesine karar verildi (BCA, 030.10.186.282.11.).

Veba-i bakarînin hızla yayılması ve mevcut iki serum kurumunda üretilen serumun yeterli olmaması üzerine, Diyarbakır'da üçüncü bir kurumun daha açılması gerekli görülmüştü. Üretilen serum miktarının artıılması ve Diyarbakır'da serum laboratuvarının kurulması için 1924 bütçesine 239,260 liralık tahsisat konulmuştu (BCA, 030.10.186.282.13.). Diyarbakır Serum Laboratuvarı ile diğer serum kurumlarına sarf edilmek üzere 21 Ocak 1925 tarih ve 545 Numaralı Kânunla Ziraat Vekâleti bütçesine 1927 yılı sonuna kadar harcanması için 600 bin liralık ödenek konulmuştur (BCA, 030.18.01.01.17.92.13.). Ancak Başvekâlet'ten Ziraat Vekâleti’ne gönderilen 6 Şubat 1926 tarihli yazıda; Diyarbakır'da kurulması düşünülen serum laboratuvarı için bütçeye tahsisat konmasının uygun olmadığı belirtilmişti (BCA, 030.10.186.282.13.). Veba-i bakarînin yayılmaya devam etmesi üzerine İcra Vekilleri Heyeti, 21 Şubat 1926'da yukarıda ifade edilen 600 bin liradan 30 bin liranın bu mücadele bütçesine aktarılmasını kararlaştırmıştı (BCA, 030.18.01.01.17.92.13.). 1926 bütçesine ayrıca 260 bin liralık Emraz-1 Müstevliye-i Hayvaniyye Tahsisatı konulmuştu. 1926 y1lı içinde etkili olan veba-i bakarîye karşı verilen mücadelede İcra Vekilleri Heyeti, 22 Eylül 1926' da bu tahsisattan 130 bin liranın kullanılması konusunda Ziraat Vekâleti'ne izin vermişti (BCA, 030.18.01.01.21.62.5.). Ayrıca, veba-i bakarî mücadelesinde kullanılmak üzere ihtiyaç duyulan 1000 adet enjektörün tedariki için 24 Aralık 1925'te ihaleye çıkılmış ve Almanya'daki bir fabrika ile anlaşmaya varılmıştı (BCA, 030.18.01.01.18.18.5.). 
İcra Vekilleri Heyeti, 25 Temmuz 1926'da veba-i bakarî ile mücadele için batı vilâyetlerinden doğu ve güney vilâyetlerine gönderilen 60 baytara zaruri giderlerine karşıllk aylık 60 lira ve on mücadele reisine 80 lira verilmesi kararlaştırmıştı (BCA, 030.18.01.01.20.45.10.). İcra Vekilleri Heyeti aynı gün veba-i bakarî ve diğer bulaşıcı hayvan hastalıklarının bulunduğu bölgelerde geçici olarak çalıştırılmak üzere süvari ve piyade gardiyanları ile amelelerin görevlendirilmelerini de kararlaştırmıştı (BCA, 030.18.01.01.20.47.1.). 3 Ekim 1926'da İcra Vekilleri Heyeti, hastalıkla mücadelede bazı önemli geçitler ve kordon noktalarında çalıştırılmak üzere geçici gardiyanlar için düzenlenen kadroları kabul etmiştir (BCA, 030.18.01.01.21.62.13.).

13 Ekim 1921 tarihinde Türkiye-Azerbaycan ve Gürcistan hükümetleri arasında Kars’ta imzalanan antlaşmanın 8. maddesi, Türkiye ile Gürcistan Cumhuriyeti hükümetlerine sınır bölgesi halkının sınırın diğer tarafındaki kışlık ve yazlık "mutad meralar"dan faydalanmak maksadıyla hayvanlarını sınırdan geçirebilme hakkını vermişti (Erk ve Akkerman, 1969, 67). Bu antlaşma hükümlerine uyarak her iki taraf meralarından faydalanacak hayvanların bulaşıcı hastalıklardan korunması, Kafkaslarda ve bazı doğu vilâyetlerinde devam etmekte olan veba-i bakarîye karşı alınacak tedbirlerin belirlenmesi amaciyla Batum'da düzenlenecek konferansa katılacak Diyarbekir Mebusu ve Halk Fırkası Müfettişi İbrahim Tali, Umur-u Baytariye Müdüri Umûmisi Ali Rıza ve Bakteriyolojihane-i Beliye Müderrisi Şefik beylerden oluşan heyete yevmiye ve pasaport verilmesi İcra Vekilleri Heyetince 8 Aralık 1926'da kabul edilmişti (BCA, 030.18.01.01.22.75.2.). Ayrıca konferansa katılacak olan bu heyete 5 Ocak 1927 'de avans verilmesi kararlaştırılmıştı (BCA, 030.18.01.01.22.82.19.). Türkiye ile Gürcistan arasında yapılan görüşmeler sonunda esasları 1926 y1lında Batum'da hazırlanan ve 6 Ağustos 1927 tarihinde Ankara'da imzalanan Veteriner Mukavelenamesi ile Meralar Mukavelesi ve bunlara bağlı protokoller imzalanmıştı (Erk ve Akkerman, 1969, 67).

Ziraat Vekâleti'nden 31 Aralık 1926'da Başvekâlet'e yazılan yazıda; Hakkâri, Mardin ve Urfa vilâyetlerine sınırdaş aşiretlerin hayvanlarından bulaşan ve Türkiye'de zaman zaman ortaya çıkan, ülkenin ekonomisi üzerinde büyük hasarlar açan veba-i bakarî hakkında Türkiye tarafindan yapılan fenni ve sıhhi tedbirlerin karşı taraf aşiretleri tarafından ciddiyetle takip edilmediği ve bu durumun Türkiye tarafından alınan önlemleri etkisiz bıraktığı vurgulanmıştı. Bu nedenle veba-i bakarînin daha fazla tahribat yapmasına meydan vermemek ve zuhur ettiği mahalde tamamen yok edilmesi imkânlarını sağlamak üzere müşterek Hudut Sıhhat Zabıtası kurmak için, Suriye ve Irak hükümetleri ile Türkiye tarafından ikişer baytarın katılımıyla kararlaştırılacak mahalde bir kongre düzenlenmesi ve kararlaştırılacak esaslara göre tedbirler alınarak hastalığın işbirliği ile imhasına çalışması konusunda Hariciye Vekâleti'nden Suriye ve Irak hükümetlerine bildirilmesi istenmişti. Yapılan yazışmalardan sonra söz konusu kongrenin Mardin'de düzenlenmesi kararlaştırılmış ve bu konudaki karar Fransa ve İngiltere'ye de bildirilmişti (BCA, 030.10.186.282.15.). Sınır bölgelerindeki vilâyetlerde veba-i bakarî ile mücadele için serum ve tedavi yöntemlerinin yaygınlaştırılmasına dikkat çekilmişti (TBMM ZC, D: III, C: 4, İ:70, (3.5.1928): 17.). 5 Nisan 1926'da TBMM'de hayvancıllğın salgın hastalıklardan korunması için hastalığın etkili olduğu bölgelerde her cins sığırın ticaretinin yapılmasını yasaklayan 1/756 Sayılı Kânun çıkarılmıştı (TBMM ZC, D: II, C:24, İ: 83, (5.4.1926),61-62.).

1927'de bir önceki yıldan kalan veba-i bakarînin tahribatı giderilmeye çalışılmıştı. Ancak İran sınırının Van'ın Saray Kazası istikametinden aşan mülteciler, hayvanları ile veba-i bakarîyi 8 Mayıs 1927'de Saray Kazası merkezine bulaştırmış ve hastalık Van merkezine bağlı Alay Köyü bölgesine de bu yolla intikal etmişti. Kuzey bölgesinde Erzurum hayvan pazarından alınan hayvanlar hastalığ Rize'ye bulaştırmıştı. Türkiye'yi dışarıdan tehdit eden hastalığa karşı ilk sınır teşkilâtı da aynı yılda kurulmuştu. Ruslarla Batum'da imzalanan Baytarî Antlaşması gereğince Rize, Artvin, Kars ve Bayazit vilâyetleri İktisat Vekâleti'nin 28 Haziran 1927 tarihli emirnamesi ile sınır teşkilatına katılmıştı. 
Teşkilat işe başladıktan sonra Rusya ile Türkiye arasında olan hayvan geçişi ciddi bir kontrole tabi tutulmuştur (Erk ve Akkerman, 1969, 103-106). Güneyde Suriye ve Irak sınırları, üzerinde yerleşmiş bulunan ve her iki tarafta arazisi bulunan halkın karşılıklı temaslarının doğurabileceği tehlikeleri önlemek amacıyla gerekli olan tedbirler 17 Kasım 1927 tarihinde Adana'da yapılan toplantılarla tespit edilmişti (Erk ve Akkerman, 1969, 68). İcra Vekilleri Heyeti, 18 Ağustos 1927'de veba-i bakarînin yok edilmesi ve çevresine bulaşmasının önlenmesi için ücretleri Ziraat Vekâleti bütçesinden ödenmek üzere 12 baytarın görevlendirilmesini kararlaştırmıştı (BCA, 030.18.01.01.25.46.12.).

1928'de ise "Zabıta-i Sihhiye-i Hayvaniyye Kanunu" yürürlüğe konulmuştu. Kanun uyarınca, pek çok hastalığın "ihbarı mecburî hastalıklar" kapsamına alınarak mücadelesi zorunlu hale getirilmişti. Ülke içerisinde ve sınırlarda, hayvan ve hayvansal maddelerin ihracat ve ithalatının yapıldığı sınır ve iskelelerde uygulanacak sağlık zabıtası kuralları ile hastalığın görülmesi durumunda alınacak önlemler, hayvan nakil ve ticareti, ihbar, tazminat ve cezai hükümler de kanunda yer almıştı (Gül, 2004, 238-239).

1928 yılında kuzey bölgesinde geçen yılın hastalıkları ile mücadele edilmiş Erzurum'dan batıya götürülen hayvanlar veba-i bakarîyi Tercan ve daha batıdaki bölgelere bulaştırmıştı. Güneyde, Diyarbakır'da mücadelesi yapılan hastalık sahasından ve Dicle yönünden Siirt'in Fındık Nahiyesi'ne bulaşan veba-i bakarî aynı zamanda buradan Mardin'in Midyat Kazası'na geçmişti. Özellikle süreklerin yıllardan beri doğudan sürükleyip getirdikleri veba-i bakarî salgınının önünü almak amacıyla 15 Nisan 1928'de bir talimatname çıkarılmıştı (Erk ve Akkerman, 1969, 108). Bu talimatnamenin hayvan hareketlerinin kontrolü, bilhassa epidemiyoloji bakımından Türkiye için hayati önemi olan ve batı memleketlerine benzeri olmayan bir takım ihtiyaçları karşılayacak durumda bulunmaması yeni kânun ve nizamnâmelerin yapılması zorunluluğunu doğurmuştu. Bu nedenle idari, teknik ve sosyal vazife, salahiyet ve mesuliyetleri ölçülü olarak tespit eden 6 Mayıs 1928 tarihli ve 1234 Sayılı "Hayvanların Sağlık Zabitası Kânunu” ve bu kanunun tatbiki hükümlerini ihtiva etmek üzere "Hayvanların Sağglı Zabıtası Nizamnamesi” kabul edilerek 9 Ağustos 1931 tarih ve 11656 Say1 ile yürürlüğe konulmuştu (Erk ve Akkerman, 1969, 47).

12 Ağustos 1928'de İcra Vekilleri Heyeti, 27 Mayıs 1921'de 28 devletin üye olmasiyla Paris'te "Beynelmilel Illlel-i Sâriye-i Hayvaniyye Dairesi" (Uluslararası Salgın Hayvan Hastalıkları Dairesi) adı altında meydana gelen daireye üye olmuştur. Türkiye'nin üye olduğu bu dairenin amacı; bulaşıcı hayvan hastalıklarını patolojik ve tahaffuzi yönden değerlendirmek, bu konudaki deneyim ve araştırmaları uluslararası çalışmalarla birleştirmek, ortak hale getirmek ve düzenlemek, salgın hastalıkların seyrini ve bunlarla mücadele için kullanılan vasıtalarla genel menfaatlere sahip belgeleri ve sağlık kayıtlarını toplayarak hükümetlerin bilgisine sunmak, hayvanların sağlık zabıtasına ait üzerinde uzlaşılmış uluslararası projeleri değerlendirmek ve bunların uygulama tarzını kolaylaştırmak olarak belirlenmişti. Bu daireye üye olmakla Türkiye'yi dışarıdan gelmesi muhtemel hastalıklardan koruma ve diğer taraftan ülke içinde etkisini sürdüren salgınların söndürülmesinde büyük faydalar sağlayacaktı. Bu amaçla 1928 bütçesine 3000 liralık ödenek konulmuştur (BCA, 030.18.01.01.30.52.3).

Salgınla mücadele kapsamında 21 Ağustos 1928 'de Diyarbakır ve Erzincan vilâyetlerinde baş gösteren veba-i bakarî mücadelesinde 80 lira ücretle istihdam olunacak 11 baytara ait kadronun yürürlüğe konulması İcra Vekilleri Heyeti'nce kabul edilmişti (BCA, 030.18.01.01.30.54.6.). Salgının Diyarbakır ve çevresinde yayılmasının önlenmesi için buradaki "Hayvan Hastalıkları Komisyonu", vilâyet sınırlarının civar vilâyetlerden getirilecek hayvanlara karşı kapatılmasını ve vilâyet dâhilindeki kaza ve nahiyeler arasındaki sığır nakliyatını yasaklayan bir karar almıştı. Muhtemel hayvan kaçakçılığının önüne geçilmesi için de jandarma ve köy bekçileri görevlendirilmişti (Diyarbekir, 23 
Ağustos 1928.). Bu dönemde ayrıca veba-i bakarî ile uluslararası mücadele kapsamında farklı ülkelerle antlaşma ve işbirliği çalışmaları süreç boyunca titizlikle sürdürülmüştü.

Türkiye ile Sovyetler Birliği arasında, sınırın iki yanında bulunan meralardan iki taraf halkının da yararlanması konusunda yapılan antlaşma 27 Şubat 1929'da uygulanmaya konulmuştu (Resmî Gazete, 5 Mart 1929, 1135, 6719.). 1929 yılında Anadolu'nun çeşitli bölgelerinde veba-i bakarî ile mücadeleye devam edilmiş ayrıca bütün sınır bölgeleri ve bunlardan hastalığın bulaşması bakımından önemli olan Rize, Artvin ve Kars ile sınırların bir hayli yakınlarına ve Doğudan Orta Anadolu'ya en çok hastalık taşıyan sürek güzergâhı ile bu bölgelere yakın alanlarda yeni bir teşkilât meydana getirilmiştir. Bu yeni teşkilât ayrıca sağlık memurları ve stajyer baytarlarla takviye edilmişti. 1930 Ağrı İsyanı'na kadar bu teşkilat iyi çalışmış, fakat isyan patlak verdikten sonra bilhassa Orta Anadolu'ya yönelen harekâtın kontrolü aksamış ve sınırlardan yeni sızmalar önlenmiş olmasına rağmen 1930'da Kayseri’ye kadar yayılan bir salgın görülmüş̧ür. ${ }^{2}$

May1s 1929 'da Mardin'de etkili olan veba-i bakarî ile mücadele etmekte olan Mücadele Heyeti Reisi Kamil Bey, Kayseri bölgesine, yerine de Baytar Müdürü Hasip Bey tayin edilmişti (Akşam, 16 Mayıs 1929.). İktisat Vekâleti, Güney ve Doğu Anadolu'da zuhur eden veba-i bakarîye karşı Mardin'de bir serum laboratuvarı açmışıı (Akşam, 18 Mayıs 1929.). Açılan bu laboratuvar Güney bölgesinin serum ihtiyacını karşılamak konusunda büyük görevler üstlenmişti. Veba-i bakarî salgınına karşı etkili serum üretme ve başka ülkelerde bu alanda yapılan çalışmalar hakkında incelemeler yapmak üzere İktisat Vekâleti Emraz-1 Sâriyye Şube Müdürü Naki Cevat ve Pendik Bakteriyolojihane Bakteriyoloğu Şefik beylerin Berlin ve Viyana'ya gönderilmeleri kararlaştırılmıştı (Akşam, 1 Temmuz 1929.).

Eylül 1929'da Kars, Artvin, Erzurum, Gümüşhane vilâyetleri ile Bayburt Kazası'nın bazı köylerinde de veba-i bakarî görülmüştü. Alınan tedbirler ve konulan kontrol sayesinde Erzurum ve Bayburt'ta hastalık etkisiz hale getirilmişti. Daha sonraki çalışmalar Artvin'in bazı kesimlerinde varlığını sürdüren hastalık üzerinde yoğunlaşmıştı (Milliyet, 18 Eylül 1929.). Buradaki hastalığın sınırdan kaçak olarak geçirilen hayvanlardan bulaştığı anlaşılmıştı (Akşam, 23 Eylül 1929.). Bu fark edilince derhal gerekli tedbirler alınmış ve sıkı bir kontrol mekanizması kurulmuştu. Bunun yanında İstanbul'da staj yapan baytarlardan 9 kişilik bir grup veba-i bakarî ile mücadele etmek amacıyla bölgeye gönderilmişti (Akşam, 15 Kânunusani 1929.). Yeni baytarlarla güçlendirilen Mücadele Teşkilâtı'nın ciddi mesai ve tedbirleri sayesinde buradaki hastalığın önüne geçilebilmişti.

1929 yılında Türkiye'nin sığır hayvancılı̆̆ı bakımından önemli bir merkezi olan Kars bölgesinde veba-i bakarî etkili olmuştu. Hastalığa karşı buradaki hayvan sağlık komisyonları ve civar vilâyetlerden gelen 21 yardımcı baytar ile vilâyet baytarları çalışmalara katılmıştı. Hastalığın en fazla etkili olduğu yerler Rusya sınırı civarında yer alan Posof, Zaruşat, Çıldır kazaları ile Kars merkeziydi. Bir önceki yıl hayvanlara bulaşan şap hastalığının tahribatı yeni atlatıldığı bir sırada veba-i bakarînin yayılması sonucu; bölgede ticaret, ziraat, nakliye vasıtası olan öküz arabalarının işlememesi köylüleri endişeye sevk etmişti (Vakit, 9 Kânunuevvel 1929.).

\footnotetext{
2 Sınır bölgelerindeki teşkilata şu vazifeler verilmiştir. 1) Sınırlardan sızması muhtemel hayvanlarla sınırın $15 \mathrm{~km}$ derinliğindeki köylerin hayvanlarının kontrol ve muayeneleri, 2) Hastalık veya şüphesi halinde icap eden mücadele için gerekli personel ve malzeme takviyesini talep etmek, 3) İcabında ve çok acil durumlarda komşu vilâyetlerden yardımcı istemek, 4) $\mathrm{Bu}$ istekleri alan otoritelerce sınır vilâyet merkezleri ile etrafinda tesis edilen ve her an emre hazır bulunan teçhizat depolarında yeteri kadar serum ve diğer malzemeyi en seri vasita ile hastalık yerine nakletmek; 5) Doğudan Orta Anadolu'ya nakledilecek sürekleri sürek talimatnamesinde yazılı esaslar dâhilinde toplama ve muayene istasyonlarında muayene ve kontrollerini yaparak her on beş günde bir defa proflaktik serumlamaya tabi tutmak, 6) İcabi halinde askeri yardım istemek ve mümkün olmayan hallerde vilâyet kanalı ile vekâlete müracaat etmek. Nihal Erk, Naki Cevat Akkerman, Türkiye'de Sığır Vebası Salgınları ve Eradikasyonu Tarihi, Ankara Üniversitesi Veteriner Fakültesi Yayını, Ankara 1969, s.109, 111.
} 
1930 yılında hastalıklı süreklerin Erzurum'da yoğunlaşan veba-i bakarîyi Amasya ve Kayseri bölgelerine taşımaları, yeni mücadele esaslarının uygulanmasını zorunlu hale getirmişti. Kaçak yolları takip eden hastalıklı sürekler, Ağrı harekâtı dolayısıyla bölgenin jandarma kuvvetlerinin hareket sahası içine alınması baytar servisinin bütün işlerini alt üst etmiş ve idari teşkilatı zor bir duruma sokmuştu ( Erk ve Akkerman, 1969:113). Bu dönemde veba-i bakarî, Kafkasya ve İran'dan sonra Kars, Erzurum ve Van vilâyetlerine bulaşmış, 1930 yazında Bitlis ve Diyarbakır vilâyetlerinde münferit vakalar halinde görülmüştü. Veba-i bakarînin bulaştığı köylerde hastalığa yakalanan ve yakalanma ihtimali bulunan civar köylerin hayvanlarına serum verilmek suretiyle hastalıkla mücadele edilmişti. Bölgede öküz arabaları ile yapılan nakliyat ve hayvan alım-satımı yasaklanmıştı. Bu dönemde hastalığı ilerleyen hayvanlar itlaf edilmiş, bedelleri karşılığı çiftçilere tazminat ödenmiş ve hayvan kaçakçıları şiddetle takip edilerek cezalandırılmıştı (Cumhuriyet, 18 Teşrinisani 1930.).

Mayıs 1930'da Erzurum'un Hasankale Kazası'nın köylerinde etkili olan veba-i bakarînin, 16 vilâyet, 44 kaza ve 338 köye bulaştığı tespit edilmişti. Bu 338 köyde 7.284 hayvanın telef olmasına sebep olmuştur. Bunlardan 1931'i kendiliğinden ölmüş, 5.043'ü tazminatll, 310'u da tazminatsız olarak itlaf edilmiştir. Hükümetçe mücadele parası olarak 103 bin lira sarf edilmiştir (Son Posta, 16 Kânunuevvel 1930.). Erzurum ve civarında veba-i bakarî hakkında tetkiklerde bulunmak için giden Ziraat Vekâleti Hastalıklar Müdürü Naki Cevat ve Fen Mütehassısı Etem beyler tetkiklerini tamamladıktan sonra Ankara'ya dönmeye karar vermişti (Milliyet, 29 Haziran 1930.). Heyet, 12 köyde yeni veba-i bakarî salgını tespit etmişti. Tespit edilen hastalığın hızlı bir şekilde etrafa yayılmasının engellenmesi ve söndürülmesi için İktisat Vekâleti, gerekli tedbirleri almıştı (Akşam, 2 Temmuz 1930.). Burada faaliyet gösteren Baytarî Heyet de teşkilâtını genişletmiş ve bölge kordon altına alınmıştı. Yapılan çalışmalara katılmak üzere iki baytar ile 10 sıhhiye memuru Erzurum'a gönderilmişti (Milliyet, 5 Temmuz 1930.). Erzurum ve çevresindeki veba-i bakarî ile mücadele etmek üzere civar vilâyetlerden çağrılan baytarlar da çalışmaya katılmıştı (Milliyet, 30 Eylül 1930.). Veba-i bakarîye karşı verilen yoğun mücadeleden sonra birkaç ay boyunca kordon altında tutulan Erzurum'da 19 Ekim 1930'da kordon kaldırılmış, merkez ile köyler arasında münakalat başlamıştı. Erzurum ekonomisine büyük darbe vuran veba-i bakarînin vilâyet dâhilindeki hayvanlarda yeni vaka görülmemesi üzerine kordonun kaldırılması halkı sevindirmiş ve burada hayvan ticareti yeniden başlamıştı. Erzurum-Trabzon ve batı Anadolu yolları sürüler için açılmıştı (Milliyet, 20 Teşrinievvel 1930.).

Sihhiye Vekâleti, Doğu vilâyetlerinde yeniden yayılmaya başlayan veba-i bakarîye karşı lazım gelen tedbirleri almış (Vakit, 27 Teşrinievvel 1930.) ve mücadele için Ankara ve civar vilâyetlerden veba-i bakarînin yoğun olduğu bölgelere yardım heyetleri göndermeyi kararlaştırmıştı. Bununla beraber İktisat Vekâleti müsteşarlarından İhsan Abidin müşavirleriyle birlikte veba-i bakarînin etkili olduğu bölgelerde tetkiklerde bulunmak üzere Doğuya hareket etmişti (Cumhuriyet, 31 Teşrinievvel 1930.).

1930 y1lında veba-i bakarî Kafkasya, İran, Irak ve Suriye'den güney ve doğu vilâyetleri ile bunlara mücavir olan Orta Anadolu'yu sarmıştı. Memleketin serum üretim merkezleri olan Pendik, Mardin, Erzincan'daki serum yetersiz kaldığından Âli Baytar Mektebi Müderrislerinden Rıza İsmail ve Ethem beyler uzun süreli koruma veren bir aşı imal etmiş ve aşı veba-i bakarîye karşı kullanılmaya başlanmıştı (Son Posta, 22 Teşrinisani 1930.). Veba-i bakarî mücadelesinde uzun zaman koruma sağlayan yeni aşının tecrübeleri hastalığın çok yayıldığı Sivas Vilâyeti köylerinde tatbik edilmeye başlanmıştı (Cumhuriyet, 18 Teşrinisani 1930; Milliyet, 18 Teşrinisani 1930; Vakit, 27 Teşrinievvel 1930; Vakit, 11 Mart 1930.). Sivas’ta ilk defa uygulanan veba-i bakarî aşısı alınan raporlara göre iyi sonuç vermişti. İcra Vekilleri Heyeti, veba-i bakarî mücadelesinde kullanılmak üzere ihtiyaç duyulan 6.000 liralık kuru serum cihazının satın alınmasını kararlaştırdı (BCA, 030.18.01.02.13.59.6.). 
Bölgede etkili olan veba-i bakarî Doğu vilâyetleri ile Sivas mıntıkasından Giresun'a kadar olan sahada yayılmıştı. Burada bulunan baytarlar çok ciddi şekilde mücadele yapmaya başlamış (Vakit, 18 Teşrinisani 1930.) ve bu kapsamında hayvan alım ve satımı yasaklanmıştı (Son Posta, 19 Teşrinisani 1930.). İran ve Kafkasya'dan yayılan veba-i bakarî, Kars, Erzurum, Bayazit, Van vilâyetlerine bulaşmıştı. Daha sonra hastalık Gümüşhane, Trabzon ve Şebinkarahisar vilâyetlerine de bulaşmış ve Bitlis, Diyarbakır, Tokat ve Kayseri vilâyetlerinde de münferit vakalar halinde görülmeye başlanmıştı (Cumhuriyet, 18 Teşrinisani 1930; Milliyet, 18 Teşrinisani 1930.).

Veba-i bakarî, 1930 yılının son aylarında Anadolu'da yayılma alanı bulmuş, yapılan mücadelelerden sonra hastalık sadece Erzurum Vilâyeti'nde kalmıştı. Erzurum'da hastalığa karşı şiddetli bir mücadele yürütülürken, Rusya'dan getirilen sığırlar yüzünden hastalık birden bire şiddetlenmiş Erzurum'dan Sivas ve Kayseri'ye kadar yayılmıştı. Bunun üzerine İktisat Vekâleti ciddi tedbirler almış ve mücadele heyetleri oluşturmuştu (Milliyet, 13 Kânunuevvel 1930.). Sivas, Kayseri civarında devam eden veba-i bakarîye karşı konulan kordon hastalığın söndürülmesi için yeterli olmamıştı (Cumhuriyet, 25 Kânunuevvel 1930.). Ocak 1931'de Sivas civarındaki salgın devam etmiş, bütün tedbirlere rağmen bölgeye yayılmıştı. Bunun üzerine Bakteriyolog Süreyya Bey'in veba-i bakarî aşısı Sivas, Kayseri ve civarında tatbik edilmeye başlanmış ve olumlu sonuçlar alınmıştı (Son Posta, 7 Kânunusani 1931.). Verilen mücadele ile hastalık genel itibariyle durmuştu (Milliyet, 18 Kânunusani 1931).

Doğu ve İç Anadolu'da veba-i bakarînin yayılması üzerine Baytar Mektebi Sârî Hastalıklar Müderrisi Riza İsmail ve Pendik Serum Enstitüsü Müdürü Ethem beyler bu havaliye gönderilmişti. Rıza İsmail Bey; "Dikkat buyrulursa bu son veba-i bakarî istilası da Ăgrı harekâtını müteakip başlamıştı. Mevcut baytarlarımız koca Anadolu'nun ancak bir vilâyeti için kâfi gelebilir" (Cumhuriyet, 22 Kânunusani 1931.) şeklinde açıklamada bulunmuştu.

Samsun ve Kayseri çevresinde de veba-i bakarî devam etmiş ve hastalığın söndürülmesi için salgın mıntıkası kordon altına alınmıştı (Son Posta, 25 Kânunusani 1931; Yarın, 25 Kânunusani 1931). Sivas Vilâyeti'ne kadar yüzü aşkın köyde yayılan veba-i bakarî (Milliyet, 15 Şubat 1931), Erzurum ve Kayseri bölgesinde mücadele heyetlerine ek olarak 20 baytar daha gönderilmişti (Cumhuriyet, 28 Şubat 1931; Yarın, 28 Şubat 1931). 1930 sonbaharında 285 köyde varlığı tespit edilen veba-i bakarîye karşı yapılan mücadele iyi neticeler vermiş ve hastalığın yayıldığı saha 22 köye inmişti (Akşam, 2 Nisan 1931). Böylece Anadolu'da veba-i bakarî olayları azalmıştı, bu nedenle hayvanların vilâyetler arasında serbestçe nakil ve satışına müsaade edilmişti (Vakit, 29 Temmuz 1931; Son Posta, 1 Ağustos 1931). Ancak salgının devam ettiği Tokat ve Zile'de hastalığın bulaşmasının önlenmesi amacıyla hayvan pazarlarında sığır ve manda alım-satımı yasaklanmıştı (Son Posta, 18 Eylül 1931.). Bu mevsimde Mersin'de veba-i bakarî tespit edilmiş ve hayvan sağlık komisyonu şehri kordon altına almıştı. Çift tırnaklı hayvanların şehre getirilmesi de yasaklanmıştı (Akşam, 12 Teşrinievvel 1931; Vakit, 12 Teşrinievvel 1931). Öte taraftan Van, Muş, Kars ve Erzurum mıntıkalarındaki veba-i bakarînin etkisi kırılmıştı (Cumhuriyet, 15 Teşrinievvel 1931; Vakit, 15 Teşrinievvel 1931).

Yüksek Baytar Mektebi Muallimi Süreyya Tahsin Bey sığır vebası ile mücadele için yeni bir usul bulmuştu (BCA, 030.10.8.48.20.). Bu döneme kadar sığır vebasında takip edilen 2 usul vardı. 1. Serum vermek, 2. Serum virüsü vermek. 1930'da Serum Müessesesi Müdürü Etem, Emraz-1 Sariye Müderrisi Rıza İsmail Beyler müşterek bir çalışma ile formüllü bir veba aşısı yapmışlardı. Fakat bu aşıyı taze taze kullanmak mecburiyeti bulunmaktaydı. Bu durum serumun üretim merkezinden uzak vilâyetlere nakli ve kullanımı zordu. Süreyya Tahsin Bey'in bulduğu yeni usulden sonra mücadele iki tarzda yapılacaktı. 1) hastalıklı mıntıkalarda serumla birlikte verilecek, bir gün sonra koruma başlayacaktı. Böylece bölge hayvanları hastalığa karşı 6 ay kadar süren bir korumaya kavuşacaktı. 2) hastalık olmayan mıntıkalarda doğrudan doğruya tatbik olunacaktı. Bu usulde on gün sonra koruma 
sağlayacaktı. Bu yeni mücadele tarzı ile veba-i bakarînin tamamen ortadan kalkacağı tahmin edilmekteydi. Süreyya Tahsin Bey'in bulduğu kurutulmuş aşı usulü mücadelede önemli bir yer tutmuş ve bu yöntem hakkında bir konferans vermişti. "Sı̆̆ır vebasından kurutulmuş aşı ile mücadele usulü" konulu, konferansta birçok mütehassısla beraber Bakteriyolojihane Müdürü Şefik, Serum Müessesesi Müdürü Ethem, Emrazı Sâriye Müderrisi Rıza İsmail beyler hazır bulunmuşlardı (Vakit, 27 Teşrinievvel 1931). 18 Eylül 1933'te çıkarılan kararnâme ile yeni bulunan dayanıklı veba-i bakarî aşısının hazırlanmasına yarayan cihaz için yapılacak tadilat hakkında bilgi vermek ve tecrübe kontrollerinde bulunmak üzere Süreyya Tahsin Beyin Almanya'ya gönderilmesine izin verilmişti (BCA, 030.18.01.02.39.67.5.). İcra Vekilleri Heyeti, 15 Ocak 1934'te, yeni bulunan dayanıklı veba-i bakarî aşısının kurutulması, toz haline getirilmesi, otomatik bir şekilde ölçülmesi ve ambalaj işleri için gerekli olan ve 14 bin liraya kadar alınabileceği anlaşılan cihaz ve aletlerin pazarlıkla Almanya'daki Nobiloz Fabrikası'ndan satın alınması kararlaştırılmıştı (BCA, 030.18.01.02.42.2.8.).

1931 sonlarında Veba-i Bakarî Mücadele Heyeti Reisi Etem Bey, Trabzon ve Erzurum'da incelemeler yapmıştı. Bu dönemde Erzurum Vilâyeti'nde yapılan mücadele neticesinde hastalık etkisiz hale gelmişti. Erzurum'a komşu olan ve çok hayvan yetiştirip ihraç eden Kars, Bayezit vilâyetlerindeki veba-i bakarî ile mücadele işi Etem Beye verilmişti. Bundan başka Ağrı Dağı sınırından batı vilâyetlerine nakledilen aşiretlere ait hayvanlara yapılacak aşılara da Etem Bey'in nezaret etmesi kararlaştırılmıştı (Akşam, 18 Teşrinisani 1931.).

Planlamaya göre 1932'de Türkiye'de veba-i bakarînin tamamen yok edilmesi y1lı olacaktı. Özellikle doğu sınırlarından yeni sızmaları önlemek amacı ile bu sınırlar üzerinde yoğun bir tarama faaliyetine geçilmiş ve 1931'den 1932'ye devredilen hastalık odaklarından Bayazıt, Kayseri, Tokat ve bunlara bağlı kaza ve köylerde ordu ve jandarma birlikleriyle taramalar yapılmıştı ( Erk ve Akkerman, 1969:127). Eylül 1932 'de Musul civarında veba-i bakarînin varlı̆̆ı haber alınmış ve bilhassa Hakkâri'nin sınır köylerinin hayvanlarına tedbir amaçlı serum verilmişti (Son Posta, 16 Eylül 1932; Milliyet, 16 Eylül 1932). Ziraat Vekâleti veba-i bakarî ile bir mücadele teşkilatı için bir layiha hazırlamıştı. Bu teşkilat, sıtma mücadelesi gibi müstakil bir teşkilata dönüştürülmesi ve bütün yurda yayılması planlanmıştı. Teşkilatta 34 baytar 70 küçük sıhhiye memuru, 30 piyade ve 70 süvari gardiyanın istihdam edilmesi, gerektiğinde asker ve jandarma kuvvetlerinin de desteğinin sağlanması da planlanmıştı (Cumhuriyet, 14 Kânunusani 1932; Vakit, 14 Kânunusani 1932).

Eylül 1932 'de mücadele heyetlerinin gerek sinırlarda ve gerekse bu hastalıktan dolayı şüphe altında bulunan mıntıkalarda yaptıkları arama ve taramalarda da hastalık bulunmadığından Türkiye'nin veba-i bakarîden kurtulduğu ilan edilmişti (Milliyet, 18 Eylül 1932; Son Posta, 18 Eylül 1932). Böylece özellikle Doğu vilâyetlerinin en büyük dertlerinden olan veba-i bakarî (Son Posta, 14 Teşrinievvel 1932; Vakit, 27 Mayıs 1933) önlenmişti. Yapılan taramalardan Aralık 1932 itibariyle Türkiye'nin hiçbir yerinde veba-i bakarî tespit edilmemişti (Cumhuriyet, 13 Kânunuevvel 1932; Haber-Akşam Postası, 26 Eylül 1934). Bunun üzerine Tarım Bakanı Muhlis Erkmen, veba-i bakarîden 1920 'de yılda 25 bin hayvanın telef olduğunu, 1933'te ise bu oranın sıfıra indiğini ifade etmişti (Ulus, 17 Mayıs 1935; Milliyet, 29 Teşrinievvel 1933.).

Veba-i bakarî, Ziraat Vekâleti tarafindan tecrübeli baytarlardan oluşturulan ve her türlü teçhizata sahip mücadele gruplarının yoğun çalışmaları, jandarma, gardiyan ve fen memurlarının da dâhil olduğu ve idarecilerin işbirliği yaptığı yoğun mücadelelerden sonra yok edilmişti (Birinci Genel Müfettişlik, 1939, 422-423). Hayvan sağlı̆̆ konusunda Türk Silahlı Kuvvetleri bünyesinde yetişen baytar subayların da önemli katkıları olmuştu (Özalper, 2020, 94). Halka yıllık 600 bin liradan fazla zarar verdiren bu hastalıkla mücadele için Cumhuriyet'in ilk on yılında, devlet her sene ortalama olarak 150 bin lira sarf etmişti (1923-1933, Cumhuriyet Halk Fırkası, 1934, 118). 


\section{Sonuç}

Veba-i bakarî tarihte insanllğı etkileyen önemli salgınlardan biridir. Salgın, bütün dünyada olduğu gibi Osmanlı Devletinde etkili olmuş, zaman zaman ülke hayvancılığına büyük kayıplar verdirmiştir. Birinci Dünya Savaşı ve Millî Mücadele dönemlerinde veba-i bakarî cephelerde savaşan ordunun nakliyat ve beslenmesinde kullanılan sığırları yok etmiştir. Bu durum ordunun hareketini etkilemiş ve ülke ekonomisine darbe indirmiştir.

Cumhuriyet Döneminde veba-i bakarî, nüfusunun yüzde $75^{\prime}$ 'inden fazlası tarım ve hayvancılıkla geçinen Türkiye'nin ekonomik hayatına oldukça olumsuz etkiler yapmıştır. Bu nedenle Cumhuriyetin ilanından sonra da hastalığa karşı mücadeleler verilmiştir. Bu dönemde veba-i bakarî, ağırlıklı olarak komşu ülkeler olan Sovyet Rusya, İran, Irak ve Suriye'den Anadolu'ya yayılmıştır. Doğu ve güney sınır bölgelerinden yapılan hayvan ticareti ve kaçak olarak yurda sokulan aşiret ve göçebe hayvanlarından da bulaşan hastalık, ülkenin temel ekonomi kaynağı, halkın geçim vasıtası olan hayvanları yok etmişti. Bu dönemde hükümet, veba-i bakarî salgınından halkı korumak amacıyla idari, sıhhi ve inzibati tedbirler alarak, sınırların muhafazası ve gümrük teşkilâtlarının da sıkı bir iş birliğiyle hastalık yok edilmiştir. Böylece eski zamanlarından beri Türkiye'de yerleşmiş bulunan ve yılda binlerce hayvanın telef olmasından doğan büyük zararların önüne geçilmiştir.

\section{Kaynakça}

1) Arşiv Belgeleri

1.1. Cumhurbaşkanlığı Devlet Arşivleri Başkanlığı Osmanlı Arşivi (BOA)

BOA, BEO, 1209. 90669.

BOA, BEO, 2967. 222490.

BOA, BEO, 2957. 221720.

BOA, BEO. 1061.79522.

BOA, DH-ŞFR, 483. 19.

\subsection{Cumhurbaşkanlığı Devlet Arşivleri Başkanlı̆̆ Cumhuriyet Arşivi (BCA)}

BCA, 030.10.13.77.25.

BCA, 030.10.186.282.11.

BCA, 030.10.186.282.13.

BCA, 030.10.186.282.14.

BCA, 030.10.186.282.15.

BCA, 030.10.186.282.2.

BCA, 030.10.186.282.9.

BCA, 030.10.57.381.13.

BCA, 030.10.8.48.20.

BCA, 030.18.01.01.12.64.16.

BCA, 030.18.01.01.16.66.2.

BCA, 030.18.01.01.16.70.20.

BCA, 030.18.01.01.17.80.9.

BCA, 030.18.01.01.17.92.13.

BCA, 030.18.01.01.18.18.5.

BCA, 030.18.01.01.20.45.10.

BCA, 030.18.01.01.20.47.1.

BCA, 030.18.01.01.21.62.13.

BCA, 030.18.01.01.21.62.5. 
BCA, 030.18.01.01.22.75.2.

BCA, 030.18.01.01.22.82.19.

BCA, 030.18.01.01.25.46.12.

BCA, 030.18.01.01.30.52.3.

BCA, 030.18.01.01.30.54.6.

BCA, 030.18.01.01.7.25.9.

BCA, 030.18.01.02.13.59.6.

BCA, 030.18.01.02.14.46.14.

BCA, 030.18.01.02.39.67.5.

BCA, 030.18.01.02.42.2.8.

BCA; 030.18.01.01.9.20.2.

2) Resmî Yayınlar

1923-1933 [Cumhuriyet Halk Firkas1, Ankara 1934].

1940-1941 Ders Yılına Başlarken Ziraat Vekili Muhlis Erkmen'in ve Rektör Süreyya Genca'nın Nutuklarl, (1940), Ziraat Vekâleti, Yüksek Ziraat Enstitüsü Neşriyatı, Ankara.

Doğu, Cümhuriyetin 15 'inci Yılında, (1938), Üçüncü Umumî Müfettişlik Yayını.

Güney Doğu, Birinci Genel Müfettişlik Bölgesi, (1939), İstanbul, Cumhuriyet Matbaası.

İstiklâl Harbinin Baytarî Harp Tarihi, Methal-Merkez ve Umumî Cephe, (1933), Harp Tarihi Encümeni Neşriyatından, İstanbul, Askerî Matbaa.

Resmî Ceride, 26 Teşrinisani 1341, No: 229.

Resmî Gazete, 5 Mart 1929, Sayı:1135.

TBMM ZC, D: II, C:24, İ: 83, (5.4.1926).

TBMM ZC, D: III, C: 4, İ:70, (3.5.1928).

TBMM ZC, D:1, C:26, İ:165, (30.12.1338).

TBMM ZC, D:1, C:28, İ:8 (21.3.1339).

TBMM ZC, D:2, C:19, İ:12, (21.11.1925).

TBMM ZC, D:2, C:19, İ:12, (21.11.1925).

TBMM ZC, D:I, C:23, İ: 118, (12.10.1338)

Birinci Köy ve Ziraat Kalkınma Kongresi Raporlarl, (1939), Ankara, Ziraat Vekâleti Neşriyat Müdürlüğü Yayını.

Idare Dergisi, Nisan 1942, Say1:168.

3) Yerel ve Ulusal Gazeteler

Akşam

Cumhuriyet

Diyarbekir

Haber-Akşam Postası

Milliyet

Son Posta

Ulus

Vakit

Varlık

Yarın

4) Makale, Kitap ve Gazete Haberleri

"Bakarî Veba", (1931), Milliyet, 15 Şubat.

“Erzurm’da Vebayı Bakarî Kordonu Kaldırıldı”, (1930) Milliyet, 20 Teşrinievvel

"Fen Âleminde", (1930), Vakit, 11 Mart.

"Hayvan Hastalığı", (1929), Akşam, 16 Mayıs.

"Hayvan Hastalığının Önüne Geçilemedi”, (1931), Son Posta, 7 Kânunusani.

“İhsan Abidin Bey Şarka Gitti”, (1930), Cumhuriyet, 31 Teşrinievvel.

"İran'dan gelen Vebai Bakarı̂”, (1930), Milliyet, 18 Teşrinisani.

“İran'dan gelen Vebai Bakarî”, (1930), Milliyet, 18 Teşrinisani.

“Memlekette Hayvan Hastalığı Henüz Nihayet Bulmadı”, (1931), Son Posta, 25 Kânunusani. 
“Memlekette Sı̆̆ır Vebası Yoktur”, (1932), Cumhuriyet, 13 Kânunuevvel.

“Mersin’de Sı̆̆ır Vebası”, (1931), Akşam, 12 Teşrinievvel.

“Mersin’de Sığır Vebası", (1931), Vakit, 12 Teşrinievvel.

“Muş’ta Öküz Vebası Hastalığı Kalmadı”, (1932), Son Posta, 14 Teşrinievvel.

“Öküz Vebası Çok Zarar Verdi”, (1930), Son Posta, 16 Kânunuevvel.

“Öküz Vebası”, (1930), Vakit, 18 Teşrinisani.

"Serum Darülistihzarı", (1929), Akşam, 18 Mayıs.

"Sı̆̆ır Vebası Hafifleşti”, (1931), Milliyet, 18 Kânunusani.

“Sığır Vebası İle Mücadele”, (1930), Milliyet, 30 Eylül.

"Sı̆̆ır Vebası İle Mücadele”, (1931), Vakit, 27 Teşrinievvel.

“Sığır Vebası Kalmadı", (1931), Son Posta, 1 Ağustos.

"Sı ğır Vebası Kalmadı", (1931), Vakit, 15 Teşrinievvel.

"Sığır Vebası Kalmadı", (1932), Milliyet, 18 Eylül.

“Sığır Vebası Kalmadı", (1932), Son Posta, 18 Eylül.

"Sığır Vebası", (1931), Akşam, 18 Teşrinisani.

"Sığır Vebası", (1931), Cumhuriyet, 22 Kânunusani.

"Sı ğır Vebası”, (1931), Cumhuriyet, 28 Şubat.

"Sığır Vebası”, (1931), Vakit, 29 Temmuz.

"Sı̆̆ır Vebası", (1931), Son Posta, 18 Eylül.

"Sı̆̆ır Vebasının Önüne Geçildi”, (1931), Cumhuriyet, 15 Teşrinievvel.

"Şark Vilâyetlerimizde Vebai Bakarî Vardır”, (1930), Son Posta, 22 Teşrinisani.

“Şark Vilâyetlerimizde Vebai Bakarî”, (1930), Son Posta, 19 Teşrinisani.

"Şark Vilâyetlerinde Vebayı Bakarî Kalmadı", (1929), Milliyet, 18 Eylül.

“Şark Vilâyetlerinde Vebayi Bakarî”, (1930), Milliyet, 13 Kânunuevvel.

"Şarkta Vebayı Bakarî Tamamen Gideriliyor”, (1933), Vakit, 27 Mayıs.

“Şarktaki Vebai Bakarî”, (1930), Cumhuriyet, 25 Kânunuevvel.

“Tarım Bakanının Söylevi”, (1935), Ulus, 17 Mayıs.

"Vabai Bakarî”, (1929), Akşam, 23 Eylül.

"Vebai Bakarî, Şark Vilâyetlerinde Hastalık Şiddetle Hüküm Sürüyor”, (1930), Cumhuriyet, 18

Teşrinisani.

"Vebai Bakarî, Şark Vilâyetlerinde Hastalık Şiddetle Hüküm Sürüyor”, (1930), Cumhuriyet, 18

Teşrinisani.

"Vebai Bakarî, Şiddetle Mücadele Başladı”, (1931), Yarın, 28 Şubat.

"Veba-i Bakarî”, (1931), Yarın, 25 Kânunusani.

"Vebai Bakarî", (1932), Milliyet, 16 Eylül.

"Vebai Bakarî", (1932), Son Posta, 16 Eylül.

"Vebai Bakarîle Mücadele", (1930), Vakit, 27 Teşrinievvel.

"Vebai Bakarîyle Mücadele Teşkilâtı Yapılıyor”, (1932), Vakit, 14 Kânunusani.

"Vebayı Bakarî Hakkında Tetkikat", (1929), Akşam, 1 Temmuz.

"Vebayı Bakarî Mücadelesi”, (1929), Akşam, 15 Kânunusani.

"Vebayı Bakarî Mücadelesi”, (1930), Milliyet, 5 Temmuz.

"Vebayı Bakarî Mücadelesi”, (1932), Cumhuriyet, 14 Kânunusani.

"Vebayı Bakarînin İntişar Sahası Daraldı", (1931), Akşam, 2 Nisan.

A. Ş., (1938), "Cumhuriyet Devrinde Türk Veterinerleri”, Akşam, 25 Teşrinievvel.

Ak, M. (2016), “Osmanlı Devleti’nde Veba-i Bakarî (Sı̆̆ır Vebası)”, OTAM, 39 /Bahar, s. 215-240.

Gül, R, T, B, (2004), Türkiye'de İki Dünya Savaşı Arasında Veteriner Hekimliği Hizmetleri ve Hayvancılık Politikaları Üzerine Araştırmalar, OTAM, S: 15, s.227-255.

Necat, İ, (1929), "Kars’ta Hayvan Hastalı̆̆ı", Vakit, 9 Kânunuevvel.

Erk, N, Akkerman, N. C, (1969), Türkiye'de Sığır Vebası Salgınları ve Eradikasyonu Tarihi, Ankara Üniversitesi Veteriner Fakültesi Yayını, Ankara.

Özalper, M. (2020). Millî Müdafaa Vekâleti Raporlarında Türk Silahlı Kuvvetleri (1923-1933). Van Yüzüncü Yıl Üniversitesi Sosyal Bilimler Enstitüsü Dergisi, S:50, s.87-108. 
Temel, M. (2010), Atatürk Dönemi Hayvancılık Politikası, Muğla Üniversitesi Sosyal Bilimler Enstitüsü Dergisi, S:24, Bahar, s.1-33.

Yücebaş, F. (2019), Cumhuriyet Döneminde Güneydoğu Anadolu (Gaziantep-Mardin-Urfa)'ya Yapılan Kamu Harcamaları ve Yatırımlar (1923-1950), Hiper Yayın. 